\title{
The Economics of Plant Production of Household Garden
}

\author{
Jawad Atef Al-Dala'een ${ }^{1}$ \\ ${ }^{1}$ Karak University College, Al-Balqa Applied University, Al-Salt Jordan \\ Correspondence: Jawad Atef Al-Dala'een, Karak University College, Al-Balqa Applied University, Al-Salt \\ 19117, Jordan. Tel: 962-78-626-4002. E-mail: jawad.papers@gmail.com
}

Received: December 13, 2017

Accepted: January 19, 2018

Online Published: February 15, 2018

doi:10.5539/jas.v10n3p298

URL: https://doi.org/10.5539/jas.v10n3p298

\begin{abstract}
The objective of this research is to investigate the economics of household plant gardening activities. The questionnaire used as a tool for data collection. The questionnaire included different parts concerning the inputs of household gardening, the processing activities and the outputs of these activities. The household population of the study was divided into different stratum according to household income and the location of households in urban and sub-urban areas. The results showed that the garden inputs are reliable on garden size. The extent of external labor use was dependent on the household income and the size of garden. The returns of household gardens were higher for trees then for vegetables.
\end{abstract}

Keywords: household gardens, net returns, expenses, returns, plant production

\section{Introduction}

Household gardens are considered very important for some families in different aspects. Some families considered the household gardens as a source of income to support the family financial activities (S. Mazumdar \& S. Mazumdar, 2012), other families consider gardens as a source of family food, while the third group consider garden as a recreational household activity. These attitudes will make differences for the method of considering the behavior of families for the management of household gardens.

Some families considered the household garden as a source of saving food for the family, other families considered a source of economic activity (Legesse et al., 2016). In both cases, the household gardens considered a tool to alleviate poverty and improve the nutritive condition of household.

The household gardens considered small-scale activities that can face difficulties through the management activities (Galhena et al., 2013). Such private condition of household production will affect and being affected of household social and economic conditions (Ninez, 1987). On the other hand, the wide species that can be planted in household gardens will increase the challenge of household to success in this activity (Gittleman, 2009). The high variation in household gardening is considered a challenge of continuity and sustainability (Addo, 2010).

Economically, the household garden should be managed in a way that accomplish added value for families and encourage the family to continue practicing these activities (Igue et al., 2000). The extent of success of garden economically depends mainly on the way the family looking for the garden. The more serious thinking of gardens as a business will increase its potential and improve its continuity and sustainability (Coomes et al., 2004; Trinth et al., 2003; Watson et al., 2002). On the other hand, household gardening participates in job creation in different urban, sub-urban and rural areas (Kobayashi et al., 2010).

The production of household garden was affected by different factors. The most important factor is the size of the garden (Gaston et al., 2005). Garden size will affect directly the type of gardening that will be handled to be profitable with the area (Dereje, 2007; VAM, 2013), and household age composition (VAM, 2013). The planting patterns of household gardens affected by the importance of the crop for the household and the added economic value the crop provide for the family (Mohan, 2004). Garden inputs highly affected by the size of the garden and the family income as well (Vogl et al., 2002). The type of plant production was affected by the climate and region (Mohan, 2004).

\section{Methodology}

Recently, the household garden production became one of the economic solutions to improve household income and nutritive value (Legesse et al., 2016). The objective of this paper is to investigate the household returns of 
gardening plant activities according to family income and location. To accomplish this objective, questionnaire used as a tool to collect data. The questionnaire designed to collect information about the socio-economic characteristics of households, plant production practices in households' gardens. The plant production included parts that was concerned for the collection of data about the input and the output of agricultural activities of household gardens. The questionnaire was prepared and tested before the collection of the final sample.

The population of this study includes all households in urban, sub-urban, and rural that contain gardens. For the purpose of this research random sample was taken. The population of this research divided into six stratum. The income and classification of household as urban or sub-urban considered in stratifying the household population. The different strata was representing different household income levels as well as the location of household garden in urban, sub-urban and rural areas. The strata were as follow:

Stratum 1: represents the people with low income

Stratum 2: represents people with low to moderate income

Stratum 3: represents people from moderate to high income

Stratum 4: represents the people with high income

Stratum 5: represents Wadi Al Ssir Area

Stratum 6: represents Amman suburbs

The collected data entered and cleaned using Excel. The data classified into two major topics including plant production. Each section of data divided to socio-economic characteristics and the inflow and outflow of the gardening activities. The collected data entered to SPSS (Ver. 22) for analysis. Excel was used to calculate and accumulate the expenses items and returns.

\section{Results and Discussion}

Before moving to investigate the economics of plant production, the first parts give some information about the practices taken over in household gardens. Figure 1 shows the results for method of household garden supervision and care in general by the family. The results showed that all household members contribute to care for gardens in different levels despite their working status. The results showed that the house women were in the first position to take care for household gardens (Igue et al., 2000). The results showed that the household wives effort is not enough to execute all gardens processes. This calls for hiring external labor work to fulfil the garden requirements especially for the large gardens area.

The least stratum that requires care for garden was the first stratum because of the low area and the low income of the family, while on the other hand the highest care was in the fourth stratum as this stratum almost contains higher gardens area with higher household incomes. The care for household gardens was taken over by females more males because of the larger time they spent in their homes. 


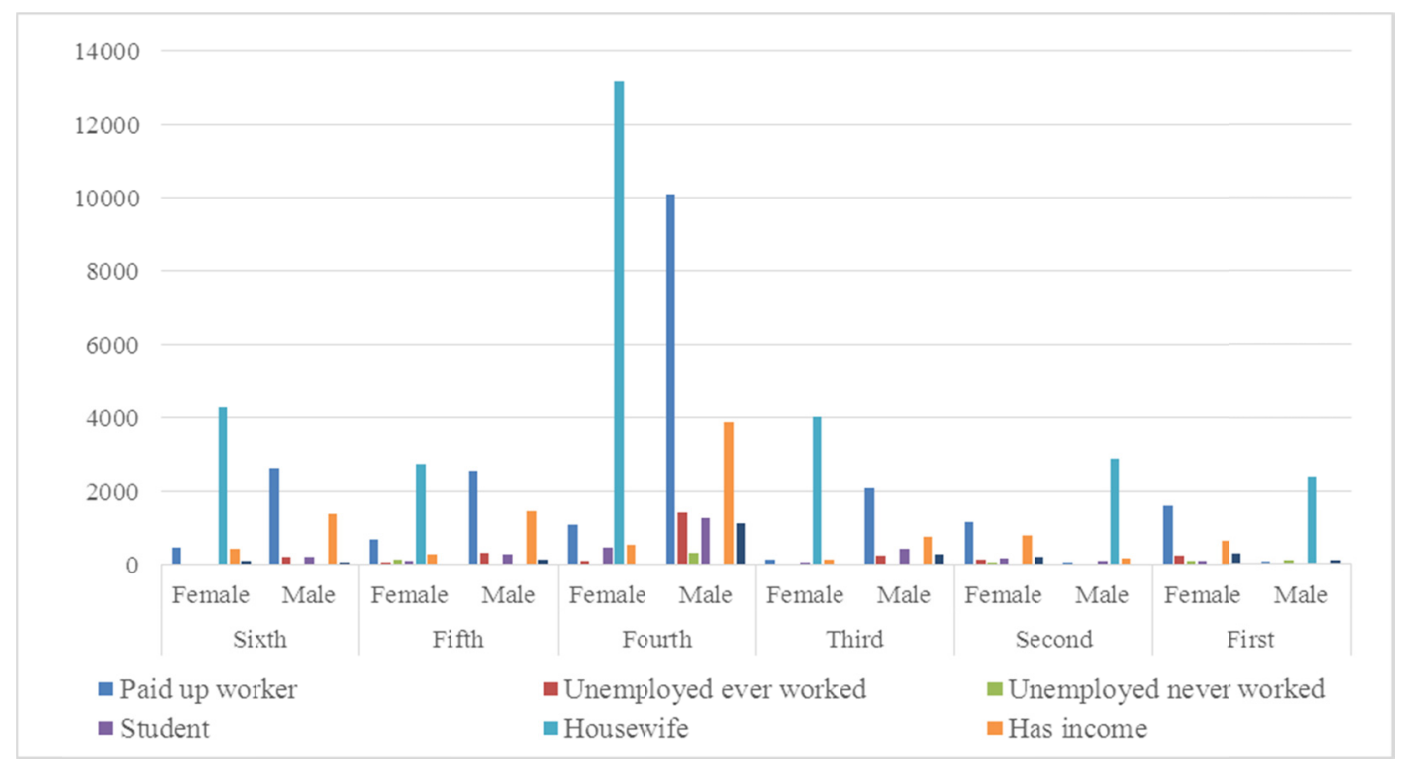

Figure 1. Distribution of household members looking after the plant production garden by sex, status of economic activity and stratum

Figure 2 shows the type of outside help given to care for household gardens. The results show that hiring labor to care for the household plant production gardens was the most dominant especially in fourth, fifth and sixth stratum which requires high work to care for plant production gardens. These three strata contains gardens with high area and households with moderate to high income.

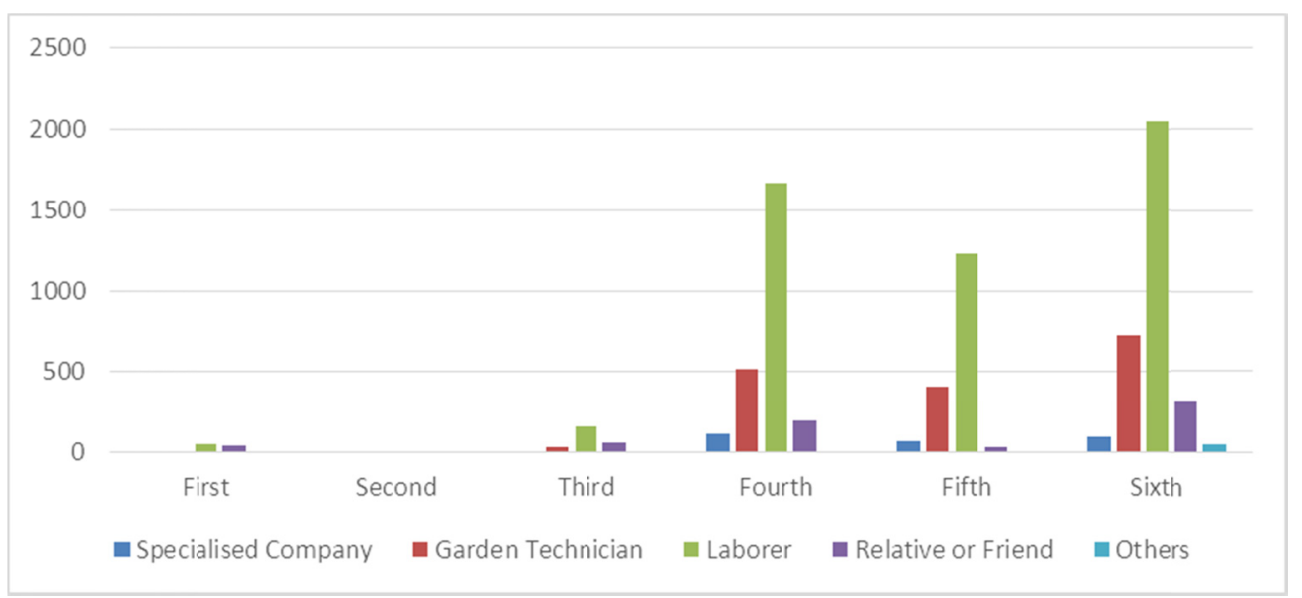

Figure 2. Distribution of gardens by method of looking after the garden excluding household members and stratum

According to garden area, the results showed that seeking for help by hiring outsources was higher in large area gardens (more $200 \mathrm{~m}^{2}$ ) (Figure 3). Garden technicians also are hired to care for gardens with very low percentage compared to laborers. 


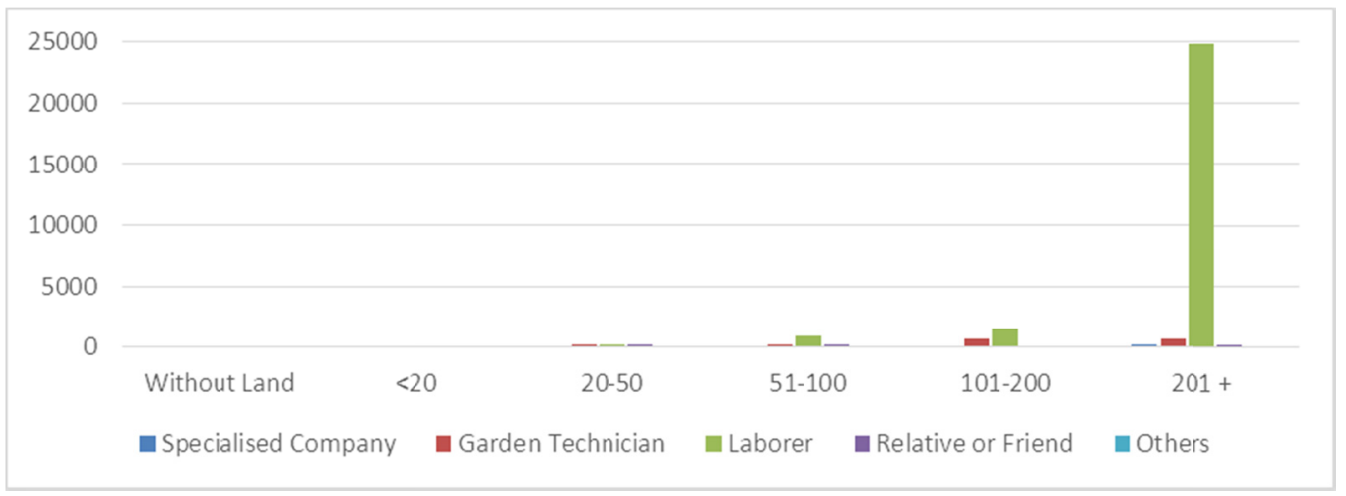

Figure 3. Looking after the garden by agency or person excluding household members by area class

Figure 4 shows some attitudes for the households concerning hiring outsources to care for gardens. The results showed that the higher objection on hiring laborers to care for garden was in the sixth stratum. Also, this point of view appeared in less emphasizes in fourth and fifth strata. In the first, second and third stratum, the attitudes were against hiring outsources to care for household gardens. The results for the fourth and fifth stratum showed higher tendency to hire outsources to care for gardens.

The first, second and third strata did not have any attitudes concerning the method of payment, satisfactory for outsources work or the method of payment as these layers did not hire outsources to care for their gardens. On the other hand, the fourth, fifth and sixth strata showed that they rely to some extent on outsources to take care for gardens. The attitude of fourth and fifth stratum will be reflected on the expenses and returns of household gardens.

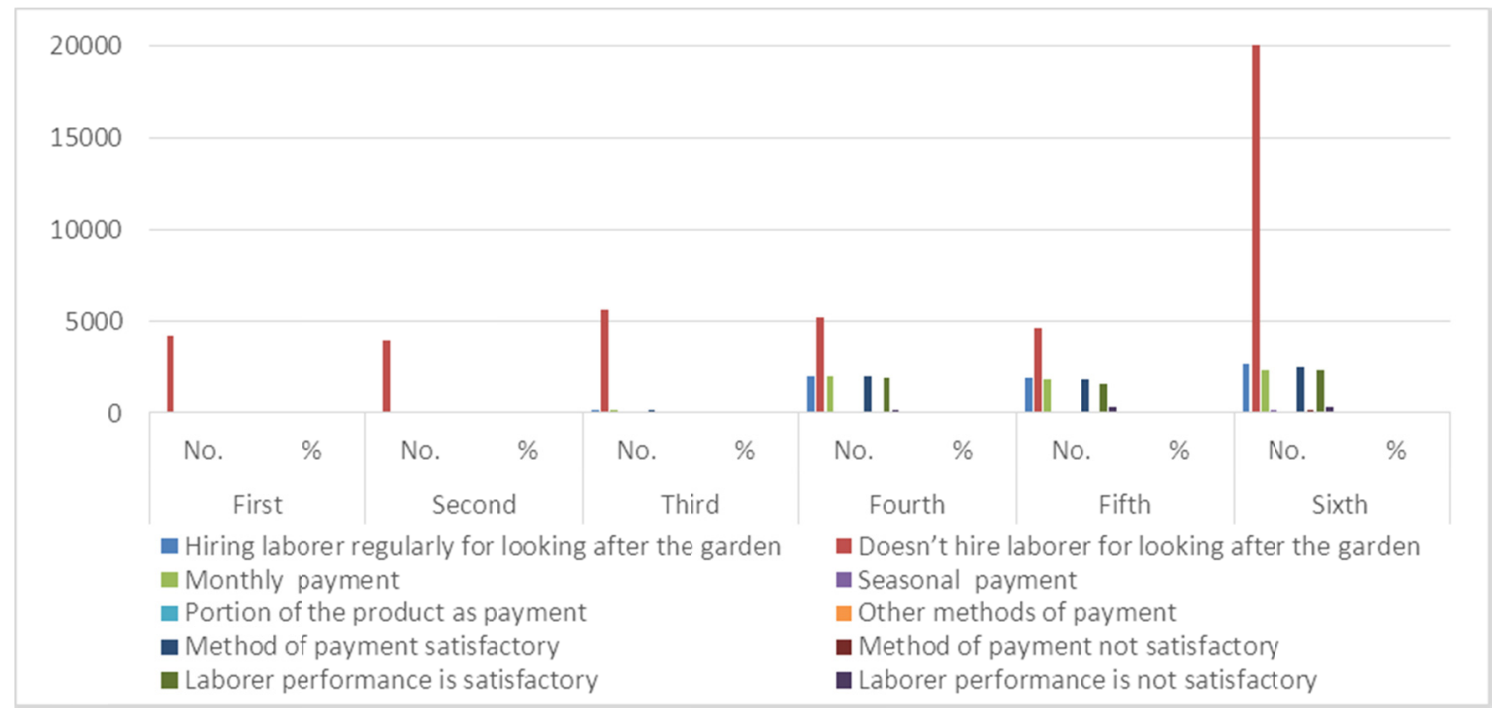

Figure 4. The household attitudes concerning outsources to care for gardens

Table 1 shows that most of families depend on their personal sources to finance the households' garden activities. Minor number of households showed that they get loans to finance the activities of household gardens (only 33). Good number of families (145) showed that they use the garden return to support the financial activities of their gardens in the coming seasons.

The pattern of saving the financial expenses for gardens was different in sixth strata due to the large area of gardens and wide variety of species in the garden. In this stratum, the sources of providing garden activities exceeded the personal supply to loans and use of returns to support activities. 
Table 1. Distribution of households by main source of finance per stratum

\begin{tabular}{|c|c|c|c|c|c|c|c|}
\hline & & & $\begin{array}{l}\text { Personal } \\
\text { Sources }\end{array}$ & Loans & $\begin{array}{l}\text { Garden Product } \\
\text { Returns }\end{array}$ & $\begin{array}{l}\text { Non } \\
\text { Applicable }\end{array}$ & Total \\
\hline \multirow{14}{*}{ 䏤 } & \multirow{2}{*}{$\begin{array}{l}\text { Total No. of } \\
\text { Households }\end{array}$} & No. & 46659 & 33 & 145 & 3261 & 50097 \\
\hline & & $\%$ & 93.1 & 0.1 & 0.3 & 6.5 & 100 \\
\hline & \multirow[t]{2}{*}{ First } & No. & 3749 & 0 & 0 & 441 & 4191 \\
\hline & & $\%$ & 89.5 & 0 & 0 & 10.5 & 100 \\
\hline & \multirow[t]{2}{*}{ Second } & No. & 3075 & 0 & 19 & 818 & 3913 \\
\hline & & $\%$ & 78.6 & 0 & 0.4 & 21 & 100 \\
\hline & \multirow[t]{2}{*}{ Third } & No. & 5018 & 0 & 0 & 675 & 5693 \\
\hline & & $\%$ & 88.1 & 0 & 0 & 11.9 & 100 \\
\hline & \multirow[t]{2}{*}{ Fourth } & No. & 6879 & 0 & 26 & 300 & 7205 \\
\hline & & $\%$ & 95.5 & 0 & 0.4 & 4.1 & 100 \\
\hline & \multirow[t]{2}{*}{ Fifth } & No. & 6300 & 0 & 0 & 176 & 6476 \\
\hline & & $\%$ & 97.3 & 0 & 0 & 2.7 & 100 \\
\hline & \multirow[t]{2}{*}{ Sixth } & No. & 21637 & 33 & 100 & 850 & 22620 \\
\hline & & $\%$ & 95.7 & 0.1 & 0.4 & 3.8 & 100 \\
\hline
\end{tabular}

Practicing agricultural activities requires good experience. Most of families showed that they get the experience to take over the garden activities through their own personal experience. Some households use books and publication as a source of their knowledge to practice the agricultural activities. Also, other households use the agricultural directorates help and private companies to manage their household gardens (Table 2). The results showed wide variety of sources to get experience to handle the agricultural processes in gardens. These activities will affect widely the expenses and the returns of gardens.

Table 2. Distribution of households by source of information on garden care and stratum

\begin{tabular}{|c|c|c|c|c|c|c|c|c|}
\hline & & $\begin{array}{l}\text { Sources of } \\
\text { Information }\end{array}$ & $\begin{array}{l}\text { Agricultural } \\
\text { Directorate }\end{array}$ & $\begin{array}{l}\text { Private } \\
\text { Companies }\end{array}$ & $\begin{array}{l}\text { Personal } \\
\text { Experiences }\end{array}$ & $\begin{array}{l}\text { Media } \\
\text { means }\end{array}$ & $\begin{array}{l}\text { Books \& } \\
\text { Publications }\end{array}$ & Others \\
\hline \multirow{14}{*}{$\begin{array}{l}E \\
\stackrel{E}{E} \\
\stackrel{E}{E}\end{array}$} & \multirow{2}{*}{$\begin{array}{l}\text { Total No. of } \\
\text { Households }\end{array}$} & No. & 2137 & 2365 & 36512 & 6094 & 1773 & 9042 \\
\hline & & $\%$ & 3.7 & 4.1 & 63 & 10.5 & 3.1 & 15.6 \\
\hline & \multirow[t]{2}{*}{ First } & No. & 359 & 33 & 3284 & 582 & $96^{\circ}$ & 497 \\
\hline & & $\%$ & 7.4 & 0.7 & 67.7 & 12 & 2 & 10.3 \\
\hline & \multirow[t]{2}{*}{ Second } & No. & 127 & 45 & 2787 & 465 & 0 & 461 \\
\hline & & $\%$ & 3.3 & 1.2 & 71.8 & 12 & 0 & 11.9 \\
\hline & \multirow[t]{2}{*}{ Third } & No. & 239 & 99 & 4594 & 370 & 95 & 662 \\
\hline & & $\%$ & 3.9 & 1.6 & 75.8 & 6.11 & 1.6 & 10.9 \\
\hline & \multirow[t]{2}{*}{ Fourth } & No. & 189 & 238 & 4920 & 385 & 196 & 1872 \\
\hline & & $\%$ & 2.4 & 3.1 & 63.1 & 4.9 & 2.5 & 24 \\
\hline & \multirow[t]{2}{*}{ Fifth } & No. & 396 & 225 & 4038 & 551 & 268 & 2176 \\
\hline & & $\%$ & 5.2 & 2.9 & 52.8 & 7.2 & 3.5 & 28.4 \\
\hline & \multirow[t]{2}{*}{ Sixth } & No. & 828 & 1724 & 16889 & 3741 & 1119 & 3374 \\
\hline & & $\%$ & 3 & 6.2 & 61 & 13.5 & 4 & 12.2 \\
\hline
\end{tabular}

The expenses of production distributed among all the garden input items with different levels (Table 3). The results showed that the least expense goes for seeds, pulps, seedlings, insecticides, fungicides, acricides, and rodenticides. While the highest expenses goes for service inputs, which form the highest in the sixth stratum due to the highest garden areas and decreased with decreasing the garden area. 
Table 3. Value of intermediate commodities and service inputs used in the garden by item and stratum (JD)

\begin{tabular}{lllllllll}
\hline \multirow{2}{*}{ Item } & \multicolumn{7}{c}{ Stratum } \\
\cline { 2 - 9 } & Sixth & Fifth & Fourth & Third & Second & First & \% & Total value \\
\hline Water & 130873.6 & 41534.4 & 35850.8 & 20746.9 & 6171.3 & 7582.0 & 8.6 & 242758.9 \\
Seeds & 11746.2 & 2859.7 & 1836.9 & 1732.4 & 363.5 & 461.3 & 0.7 & 18999.9 \\
Pulps & 5107.5 & 1384.6 & 959.8 & 843.7 & 310.9 & 285.8 & 0.3 & 8892.4 \\
Seedlings & 26356.6 & 6977.5 & 19427.7 & 3814.7 & 361.2 & 1045.3 & 2.0 & 57983.1 \\
Insecticides & 35835.4 & 10765.6 & 10653.7 & 6414.2 & 850.4 & 1749.3 & 2.3 & 66268.6 \\
Fungicides & 23006.5 & 6732.7 & 5464.8 & 2071.6 & 337.4 & 525.7 & 1.3 & 38138.8 \\
Acricides & 219.8 & 0.0 & 0.0 & 0.0 & 0.0 & 0.0 & 0.01 & 219.8 \\
Rodenticides & 249.4 & 0.0 & 0.0 & 0.0 & 0.0 & 0.0 & 0.01 & 249.4 \\
Organic fertilizers & 106614.1 & 31549.4 & 32455.5 & 9173.4 & 1942.7 & 3556.0 & 6.5 & 185291.2 \\
Chemical fertilizers & 33342.0 & 12243.6 & 10152.0 & 4232.0 & 323.1 & 1732.8 & 2.2 & 62025.5 \\
Service inputs & 708813.8 & 436429.8 & 489960.9 & 52648.0 & 9471.3 & 14486.6 & 60.3 & 1711810.0 \\
Others & 393.4 & 302.5 & 0.0 & 0.0 & 0.0 & 0.0 & 0.02 & 695.9 \\
Total & 1082558.0 & 550780 & 606762.0 & 101677.0 & 20131.8 & 31424.8 & 100.0 & 2393334.0 \\
\%of total & 49.3 & 20.1 & 21.6 & 5.9 & 1.4 & 1.7 & & 100.0 \\
\hline
\end{tabular}

Table 4 shows that the expenses for the inputs increases as the area of the garden increases. This pattern is applied for all plant garden inputs. The highest inputs recorded in the sixth stratum for all inputs. While the least inputs recorded in the first and second stratum as these two stratum has the least income and the lowest ability to expend on household gardens.

Table 4. Value of intermediate commodities used in the garden by item and area class (JD)

\begin{tabular}{lllllll}
\hline \multirow{2}{*}{ Item } & \multicolumn{5}{c}{ Area Class (Sq.) } \\
\cline { 2 - 7 } & $\mathbf{2 0 1}$ and above & $\mathbf{1 0 1 - 2 0 0}$ & $\mathbf{5 1 - 1 0 0}$ & $\mathbf{2 0 - 5 0}$ & Less than 20 & Total value \\
\hline Water & 98720.5 & 63494.1 & 42746.5 & 28549.2 & 9248.7 & 242758.9 \\
Seeds & 8615.0 & 5020.1 & 3087.7 & 1783.1 & 494.0 & 18999.9 \\
Pulps & 3873.2 & 2453.8 & 1363.2 & 938.3 & 264.0 & 8892.4 \\
Seedlings & 31906.0 & 9960.6 & 7290.9 & 7447.6 & 1378.0 & 57983.1 \\
Insecticides & 30555.5 & 18295.4 & 10114.7 & 5035.4 & 2267.6 & 66268.6 \\
Fungicides & 25373.5 & 7392.6 & 2815.7 & 2011.2 & 545.9 & 38138.8 \\
Acricides & 0.0 & 219.8 & 0.0 & 0.0 & 0.0 & 219.8 \\
Rodenticides & 249.4 & 0.0 & 0.0 & 0.0 & 0.0 & 249.4 \\
Organic fertilizers & 116863.7 & 36932.9 & 18574.6 & 9937.3 & 2982.6 & 185291.2 \\
Chemical fertilizers & 29618.3 & 16711.0 & 10564.1 & 4294.2 & 837.8 & 62025.5 \\
Service Inputs & 872886.0 & 502701.5 & 228641.3 & 95159.8 & 12421.8 & 1711810.0 \\
Others & 577.5 & 118.4 & 0.0 & 0.0 & 0.0 & 695.9 \\
Total & 1358223.8 & 817326.7 & 372634.9 & 190019.6 & 109807.5 & 2838793.8 \\
\% of total & 47.8 & 28.8 & 13.1 & 6.7 & 3.9 & 100.0 \\
\hline
\end{tabular}

The highest income of gardens activity was recorded for fruit trees products of about $1,731,185 \mathrm{JD}$, followed by vegetables with a total return of about 95,135JD (Noble, 2010). The least returns recorded for ornamental plants of about 26,795JD. The total amount of returns of household garden activities recorded was 1,927,136JD (Table $5)$. 
Table 5. Quantity and value of plant production

\begin{tabular}{|c|c|c|c|c|}
\hline Item & Unit & $\%$ & Value (JD) & Quantity \\
\hline \multirow[t]{4}{*}{ Field Crops } & $\mathrm{kg}$ & & 503.9 & 812.8 \\
\hline & Bundle & & 24.7 & 124.0 \\
\hline & Baleh & & 127.1 & 51.0 \\
\hline & Total & 0.03 & 655.7 & \\
\hline \multirow[t]{4}{*}{ Vegetables } & $\mathrm{kg}$ & & 72301.2 & 148170.5 \\
\hline & No. & & 1275.7 & 10484.0 \\
\hline & Bundle & & 21558.2 & 131892.0 \\
\hline & Total & 4.9 & 95135.1 & \\
\hline \multirow[t]{4}{*}{ Fruit Trees } & $\mathrm{kg}$ & & 72301.2 & 148170.5 \\
\hline & No. & & 127.3 & 498.0 \\
\hline & Bundle & & 11.2 & 55.0 \\
\hline & Total & 89.8 & 1731185.3 & \\
\hline \multirow[t]{3}{*}{ Aromatic and Medical } & $\mathrm{kg}$ & & 54822.9 & 58217.0 \\
\hline & Bundle & & 18541.9 & 114621.0 \\
\hline & Total & 3.8 & 73364.8 & \\
\hline \multirow[t]{5}{*}{ Ornamental plants and bushes } & $\mathrm{kg}$ & & 68.6 & 171.5 \\
\hline & No. & & 4114.8 & 16060.0 \\
\hline & Bundle & & 22612.2 & 21632 \\
\hline & Total & 1.4 & 26795.7 & \\
\hline & Grand Total & 100 & 1927136.6 & \\
\hline
\end{tabular}

The highest returns recorded for the sixth stratum for all types of products. In this stratum, households consider the household garden is a type of investment that they care for the amount of expense and the amount returns they get from their activities. In the fourth and fifth stratum, the returns were less as these two strata have intermediate to high income among the others. In the first, second and third stratum the households care for the income as it considered supported part for the household income (Table 6).

Table 6 . Value of plant production by stratum (JD)

\begin{tabular}{|c|c|c|c|c|c|c|c|}
\hline \multirow{2}{*}{ Item } & \multicolumn{6}{|c|}{ Stratum } & \multirow{2}{*}{$\begin{array}{l}\text { Total Value of } \\
\text { Production }\end{array}$} \\
\hline & Sixth & Fifth & Fourth & Third & Second & First & \\
\hline Field crops & 301.9 & 217.5 & 103.7 & 0.0 & 0.0 & 32.6 & 655.7 \\
\hline Vegetables & 57749.2 & 11759.3 & 10382.3 & 8343.9 & 1679.8 & 5220.6 & 95135.1 \\
\hline Fruit trees & 1011622.6 & 251419 & 219061 & 141681.1 & 50876.1 & 56525.5 & 1731185.3 \\
\hline Aromatic and medical plants & 46753.3 & 12956 & 5587.6 & 5977.2 & 896.0 & 1194.7 & 73364.8 \\
\hline Ornamental plants and bushes & 16286.8 & 6199.3 & 2798.1 & 1260.3 & 251.2 & 0.0 & 26795.7 \\
\hline Total & 1132713.8 & 282551.1 & 237932.1 & 157262.5 & 53703.1 & 62973.4 & 1927136.6 \\
\hline$\%$ of Total & 58.8 & 14.7 & 12.3 & 8.1 & 2.8 & 3.3 & 100.0 \\
\hline
\end{tabular}

The results in Table 7 showed that the net returns was higher in the sixth stratum followed by the first, second and third strata, while the returns were negative in the fourth and fifth stratum because these two do not care for the garden returns as part of the household income, they consider as a type of entertainment and recreation.

Table 7. Net profit of plant activities according to stratum

\begin{tabular}{lllllll}
\hline Item & First & Second & Third & Fourth & Fifth & Sixth \\
\hline Expenses & 31424.8 & 20131.8 & 101676.9 & 606762.1 & 550779.8 & 1082558 \\
Total returns & 62973.4 & 53703.1 & 157263 & 237932 & 282551 & 1132714 \\
Net Profit & 31548.6 & 33571.3 & 55585.6 & -368830 & -268229 & 50155.5 \\
\hline
\end{tabular}




\section{Conclusions}

The objective of this research is to investigate the patterns of inputs and outputs of the household gardens for plant production. The results of this research showed that the variation among the behavior pattern for the different strata was high. The care for the inputs and method of financial supply depends on the method the household deals with the garden. The sixth strata which represent the garden in the suburban areas showed more business attitudes in their management of gardens. The fourth and the fifth strata showed less business consideration for the method of garden management.

The higher expenses were shown in the sixth stratum and the highest laborer hiring was in this strata. The reason for that is the large areas of the gardens in this stratum and the higher the effort required to care for gardens.

The first, second and third strata have different procedures to manage gardens, due to low areas and low income of these families. The families of these strata considered the garden as a source of support for family in their nutrition and income, so they try their best to decrease the expenses as much as possible.

\section{References}

Addo, K. (2010). Urban and Peri-Urban Agriculture in Developing Countries, Studied using Remote Sensing and in situ Methods. Remote Sensing, 2, 497-513. https://doi.org/10.3390/rs2020497

Coomes, O. T., \& Ban, N. (2004). Cultivated plant species diversity in home gardens of an Amazonian peasant village in northeastern Peru. Econ. Bot., 58, 420-434. https://doi.org/10.1663/0013-0001(2004)058[0420: CPSDIH]2.0.CO;2

Dereje, A. (2007). Urban agriculture in Mekelle, Tigray state, Ethiopia: Principal characteristics, opportunities and constraints for further research and development. Cities, 24(3), 218-228. https://doi.org/10.1016/ j.cities.2007.01.008

Galhena, D., Freed, R., \& Maredia, M. (2013). Home gardens: A promising approach to enhance household food security and wellbeing. Agriculture and Food Security, 2, 8. https://doi.org/10.1186/2048-7010-2-8

Gaston, K., Warren, P., Thompson, K., \& Smith, R. (2005). Urban domestic garden (IV): The extent of the resources and its associated features. Biodiversity and Conversation, 14, 3327-3349. https://doi.org/ 10.1007/s10531-004-9513-9

Gittleman, M. (2009). Urban Expansion in Addis Ababa: Effects of the Decline of Urban Agriculture on Livelihood and Food Security. A paper presented at the United Nations 17th Commission on Sustainable Development.

Igue, A. M., Floquet, A., \& Stahr, K. (2000). Land use and farming systems in Benin. In F. Graef, P. Lawrence, \& M. von Oppen (Eds.), Adapted farming in West Africa: Issues, potentials and perspectives (pp. 227-238). Stuttgart, Germany: Verlag Ulrich E. Grauer.

Kobayashi, M., Tyson, L., \& Abi-Nader, J. (2010). The Activities and Impacts of Community Food Projects 2005-2009 (pp. 1-28).

Legesse, A., Tesfay, G., \& Abay, F. (2016). The impact of urban home gardening on household socio-economy. Arts and Design Studies, 39, 21.

Mazumdar, S., \& Mazumdar, S. (2012). Immigrant home gardens: Places of religion, culture, ecology, and family. Landsc Urban Plan, 105, 258-265. https://doi.org/10.1016/j.landurbplan.2011.12.020

Mohan, S. (2004). An Assessment of the Ecological and Socioeconomic Benefits Provided by Homegardens: A Case Study of Kerala, India (PhD Dissertation, University of Florida, USA).

Niñez, V. K. (1987). Household gardens: theoretical and policy considerations. Agr Syst, 23, 167-186. https://doi.org/10.1016/0308-521X(87)90064-3

Noble, C. (2010). Small plots, big hopes: Factors associated with participation in an urban garden project in Lesotho (Dissertation, University of South Florida, USA).

VAM. (2013). Food and Nutrition Security in Republic of Korea. WFP Country Office.

Vogl, C. R., Vogl-Lukraser, B., \& Caballero, J. (2002). Homegardens of Maya Migrants in the district of Palenque, Chiapas, Mexico: Implications for sustainable rural development. In J. R. Stepp, F. S. Wyndham, \& R. K. Zarger (Eds.), Ethnobiology and Biocultural Diversity (pp. 1-12). University of Georgia Press, Athens, GA. 
Watson, J. W., \& Eyzaguirre, P. B. (2002). Home gardens and in situ conservation of plant genetic resources in farming systems. Proceedings of the 2nd International Home Gardens Workshop, 17-19 July 2001, Witzenhausen, Federal Republic of German.

\section{Copyrights}

Copyright for this article is retained by the author(s), with first publication rights granted to the journal.

This is an open-access article distributed under the terms and conditions of the Creative Commons Attribution license (http://creativecommons.org/licenses/by/4.0/). 